University of Nebraska - Lincoln

DigitalCommons@University of Nebraska - Lincoln

2002

\title{
ATA2-Mediated Amino Acid Uptake Following Partial Hepatectomy is Regulated by Redistribution to the Plasma Membrane
}

\author{
Thomas L. Freeman \\ Department of Internal Medicine, University of Nebraska Medical Center, Omaha, NE, USA \\ Geoffrey M. Thiele \\ Department of Internal Medicine, University of Nebraska Medical Center, Omaha, NE, USA \\ Dean J. Tuma \\ Department of Internal Medicine, University of Nebraska Medical Center, Omaha, NE, USA \\ Tina K. Machu \\ Department of Pharmacology, Texas Tech University Health Sciences Center, Lubbock, TX, USA \\ Mark E. Mailliard \\ Department of Internal Medicine, University of Nebraska Medical Center, Omaha, NE, USA
}

Follow this and additional works at: https://digitalcommons.unl.edu/publichealthresources

Part of the Public Health Commons

Freeman, Thomas L.; Thiele, Geoffrey M.; Tuma, Dean J.; Machu, Tina K.; and Mailliard, Mark E., "ATA2-Mediated Amino Acid Uptake Following Partial Hepatectomy is Regulated by Redistribution to the Plasma Membrane" (2002). Public Health Resources. 81.

https://digitalcommons.unl.edu/publichealthresources/81

This Article is brought to you for free and open access by the Public Health Resources at DigitalCommons@University of Nebraska - Lincoln. It has been accepted for inclusion in Public Health Resources by an authorized administrator of DigitalCommons@University of Nebraska - Lincoln. 


\title{
ATA2-mediated amino acid uptake following partial hepatectomy is regulated by redistribution to the plasma membrane
}

\author{
Thomas L. Freeman, ${ }^{\mathrm{a}, \mathrm{b}}$ Geoffrey M. Thiele, ${ }^{\mathrm{a}, \mathrm{b}}$ Dean J. Tuma, ${ }^{\mathrm{a}, \mathrm{b}}$ Tina K. Machu, ${ }^{\mathrm{c}}$ and \\ Mark E. Mailliard ${ }^{\mathrm{a}, \mathrm{b}, *}$ \\ a Department of Internal Medicine, University of Nebraska Medical Center, Omaha, NE, USA \\ ${ }^{\mathrm{b}}$ Veterans Administration Medical Center, Alcohol Study Unit, Omaha, NE, USA \\ ${ }^{\mathrm{c}}$ Department of Pharmacology, Texas Tech University Health Sciences Center, Lubbock, TX, USA
}

Received 3 October 2001, and in revised form 14 January 2002

\begin{abstract}
System A, the $\mathrm{Na}^{+}$-dependent amino acid transport activity, is encoded by the ATA2 gene and up-regulated following partial hepatectomy $(\mathrm{PH})$, and its competitive inhibition interferes with liver regeneration. Rabbit polyclonal antibody was raised against a portion of the ATA2 gene product followed by immunodetection of ATA2 in isolated liver plasma membrane and lysate. The level of ATA2 increased in the plasma membrane following PH, while the relatively high quantity of ATA2 found in liver lysate remained constant. We also have shown that Northern analysis of steady-state ATA2 mRNA revealed no significant change following PH. These data show that ATA2-mediated transport is not regulated by the steady-state level of ATA2 mRNA but is regulated by the amount of ATA2 and redistribution to the plasma membrane. We hypothesize that ATA2 activity is regulated by recruitment of ATA2 protein from an intracellular compartment. In addition, the pattern of expression of System A activity in oocytes, transport kinetics, and sensitivity to chemical modification indicate the presence of a second System A isoform in liver that differs substantially from ATA2.
\end{abstract}

Keywords: System A; ATA2; Amino acid transport; Liver regeneration; Plasma membrane

Unlike any other organ, the liver can regenerate following damage or surgical resection. Following $70 \%$ resection of rat liver, this regenerative process is remarkable with the liver regaining its original mass within 7 to 10 days [23]. The early regenerative response is complex and characterized by changes in the ion flux at the hepatocyte membrane [25], changes in signal transduction and immediate early gene expression $[10,41]$, expression of oncofetal proteins [11], increased amino acid uptake [12,26,29], and induction of DNA synthesis [18]. Optimal regeneration has been shown to depend on an adequate supply of nutrients, several hormones, growth factors, and cytokines.

Adequate nutrients [5], most notably amino acids $[24,31,36]$, have been demonstrated as essential for

\footnotetext{
${ }^{*}$ Corresponding author. Present address: Section of Gastroenterology, Veterans Affairs Medical Center (111Gastro), 4101 Woolworth Avenue, Omaha, NE 68105, USA. Fax: +402-943-5570.

E-mail address: mmaillia@unmc.edu (M.E. Mailliard).
}

normal liver regeneration, but the role of specific plasma membrane amino acid transporters during liver regeneration has remained elusive. "System A," the $\mathrm{Na}^{+}$-dependent transporter of small, neutral amino acids, has received much attention in studies correlating its activity to liver regeneration $[12,14,26]$, gluconeogenesis $[19,30]$, cell volume control [22], and entry into the cell cycle [2,9,34,35]. $N$-(Methylamino)isobutyric acid (MeAIB), ${ }^{1}$ the prototypical System A substrate and a competitive inhibitor of transport [8], has been demonstrated to inhibit the robust proliferation of hepatocytes following PH [14]. Despite intense study for the past two decades,

\footnotetext{
${ }^{1}$ Abbreviations used: MeAIB, $N$-(methylamino)isobutyric acid; $\mathrm{PH}$, partial hepatectomy; HPMVs, hepatic plasma membrane vesicles; NEM, $N$-ethylmaleimide; PBS, phosphate-buffered saline; RT-PCR, reverse transcriptase-polymerase chain reaction; Ni-NTA, nickelnitrilotriacetic acid; BSA, bovine serum albumin; SDS-PAGE, sodium dodecyl sulfate-polyacrylamide gel electrophoresis; ELISA, enzymelinked immunosorbent assay.
} 
the cloning of cDNAs encoding gene products displaying transport activities partially or completely consistent with System A has only recently been reported. GlnT [42] and SAT2 [43] both transport MeAIB in a $\mathrm{Na}^{+}$. dependent manner, the property synonymous with System A activity, but neither GlnT or SAT2 is expressed in liver, implying little or no role for these genes in hepatic regeneration. Fortunately, ATA2 [38] (as well as the identical SA1 [33]) displays transport characteristics consistent with System A, is widely expressed in many tissues, and exhibits particularly strong expression in liver.

Our laboratory has previously demonstrated that the steady-state ATA2 mRNA level in regenerating liver does not correlate with the 3- to 5-fold increase in ATA2-mediated amino acid transport activity following PH [13]. These observations indicate that ATA2-mediated transport is regulated beyond the level of transcription, perhaps at the level of translation or posttranslation. Unfortunately, the study of posttranscriptional events requires a probe specific for the ATA2 gene product such as an antibody to the ATA2 protein. To meet this need, our laboratory produced affinitypurified polyclonal rabbit antibody specific for a region of the ATA2 gene product which was utilized in the measuring of ATA2 protein levels in liver tissue and hepatic plasma membrane vesicles (HPMV) following $\mathrm{PH}$.

We utilized regenerating liver as a well-described model for monitoring the regulation of ATA2-mediated transport activity at the mRNA and protein levels. We describe the regulation of ATA2-mediated transport activity by an apparent redistribution of gene product to the plasma membrane. This was found to correlate well with the steady-state mRNA level of ATA2, the expression of System A transport activity from regenerating liver mRNA in oocytes, and System A transport kinetics in HPMVs. Our results also indicate that two System A-like transport activities are induced following $\mathrm{PH}$ which differ substantially in kinetic properties and in the mechanisms of regulation.

\section{Materials and methods}

Partial hepatectomy. Adult male Sprague-Dawley rats, 200-250 g, were obtained from Harlan-SpragueDawley, Indianapolis, Indiana. All experiments were approved by the Omaha Veterans Administration Medical Center Institutional Animal Care and Use Committee and comply with the guidelines set by the National Institutes of Health. Rats were maintained under a controlled temperature with a $12 \mathrm{~h}$ light-dark cycle for at least 5 days before use in experiments. Standard rodent chow and water were provided ad libitum. Between 8 and $10 \mathrm{Am}$, animals were anesthetized with ketamine $(75-100 \mathrm{mg} / \mathrm{kg})$ and acepromazine $(2.5$ $\mathrm{mg} / \mathrm{kg}$ ) followed by $70 \% \mathrm{PH}$ as described by Higgins and Anderson [23]. Before closing of the abdominal wall, the peritoneum was filled with normal saline $(0.5 \%$ of body weight). Animals were placed on a $25-30{ }^{\circ} \mathrm{C}$ pad until alert, and then they were transferred to a cage containing food and water. Animals were reanesthetized before collection of liver at the times described in the individual experiments.

Preparation of hepatic plasma membrane vesicles. Plasma membrane-enriched vesicles were prepared from regenerating rat liver by a modification of a Percoll gradient technique [32] as previously described [12]. Plasma membrane vesicles were resuspended in SEB (250 $\mathrm{mM}$ sucrose, $1 \mathrm{mM}$ magnesium chloride, and 10 $\mathrm{mM}$ Hepes; $\mathrm{pH}$ 7.5), aliquoted, and stored at $-70{ }^{\circ} \mathrm{C}$. Each aliquot was thawed on ice and used only once. Protein content was determined by a modification of the Lowry method.

Vesicle amino acid transport assay. $\mathrm{Na}^{+}$-dependent and $\mathrm{Na}^{+}$-independent uptake of amino acid was determined as previously described [12]. Briefly, after prewarming to $37^{\circ} \mathrm{C}$ for $1 \mathrm{~min}, 20 \mu \mathrm{l}$ of an uptake solution ( 0.005 to $5 \mathrm{mM}$ labeled MeAIB, $20 \mathrm{mM}$ Hepes, $2 \mathrm{mM}$ magnesium chloride, $100 \mathrm{mM}$ sodium, or potassium thiocyanate, $\mathrm{pH} 7.5$ ) was added to a $20-\mu \mathrm{l}$ aliquot of plasma membrane vesicle solution. After $10 \mathrm{~s}$, uptake was terminated by the addition of $1 \mathrm{ml}$ of ice-cold PBS (150 mM sodium chloride and $10 \mathrm{mM}$ sodium phosphate, $\mathrm{pH}$ 7.5) followed by immediate filtration through a $0.45-\mu \mathrm{m}$ nitrocellulose filter under vacuum. The filter was washed twice with $4 \mathrm{ml}$ of ice-cold PBS. Uptake of labeled compound trapped in the vesicles was measured by scintillation spectrophotometry. Sodium-dependent uptake is expressed as picomoles of substrate per milligram of protein per $10 \mathrm{~s}$ after subtracting the uptake velocity in the absence of sodium from the uptake velocity in the presence of sodium. A $\mathrm{Na}^{+}$-dependent overshoot was observed for the concentration range of MeAIB used (data not shown). In experiments utilizing chemical modification of System A activity with $\mathrm{N}$ ethylmaleimide (NEM), vesicles were incubated in 1 $\mathrm{mM}$ NEM for $20 \mathrm{~min}$ at $37{ }^{\circ} \mathrm{C}$, and pairwise controls were incubated in an equal volume of vehicle (water) and then placed on ice. System A activity was then determined at $25{ }^{\circ} \mathrm{C}$ by the rapid filtration method described above.

Expression and purification of ATA2 fusion protein. The $5^{\prime}$ (TATGAAACAGAATTTCATCCA-OH) and $3^{\prime}$ (CAACTCATATTTCACTATGAA-OH) oligonucleotide primers were designed for use in RT-PCR to generate a 336-bp fragment of ATA2 from rat liver mRNA. Total RNA was isolated from rat liver using a QIAgen (Santa Clara, CA) total RNA kit, followed by RT-PCR using the QIAgen One-Step kit, $1 \mu \mathrm{g}$ rat RNA, and 0.4 $\mu \mathrm{M}$ of each primer. Reverse transcriptase reactions were 
exactly as described by the manufacturer, and the PCR was conducted for 30 cycles of 94,52 , and $72{ }^{\circ} \mathrm{C}$ for 1 min each. RT-PCR of ATA2 was highly specific producing only a single 336-bp product which was cloned into the pBAD-TOPO (Invitrogen, Carlsbad, CA) vector and transformed into Escherichia coli Top 10. Putative clones were screened for direction by nucleotide sequencing and evaluated for L-arabinose-inducible production of a $6 \mathrm{His}$ fusion peptide. The clone which demonstrated the best production of fusion peptide was designated pBAD:ATA2 $(0 \rightarrow 1)$ and retained for use in all subsequent experiments.

ATA2 fusion peptide was purified utilizing nickelnitrilotriacetic acid (Ni-NTA) metal-affinity chromatography. E. coli Top10::pBAD:ATA2 $(0 \rightarrow 1)$ cells were grown in $4 \mathrm{~L}$ of standard M9 media containing $0.5 \%$ glycerol, $0.005 \%$ glucose, $0.1 \%$ casamino acids, and 100 $\mathrm{mg} / \mathrm{L}$ ampicillin to an $\mathrm{OD}_{600}$ of 0.6 before a 4-h induction of fusion peptide expression with $0.04 \%$ L-arabinose. Fusion peptide was then purified using the batch purification under denaturing conditions as described by the manufacturer of the Ni-NTA resin (The QIAexpressionist Handbook, QIAgen). Peptide purity was $>99 \%$ as assessed by Coomassie stain of proteins following SDS-PAGE.

Production of polyclonal ATA2 antibody. Polyclonal antibody was prepared by injecting a portion of the ATA2 gene product, as an antigen, into New Zealand White rabbits utilizing standard protocols. The antigen was expressed in E. coli as described above and corresponds to amino acid residues 62 to 173 of the rat ATA2 gene product [38]. Adult male rabbits were obtained from Harlan-Sprague-Dawley, Indianapolis, Indiana. All experiments were approved by the Omaha Veterans Administration Medical Center Institutional Animal Care and Use Committee and comply with the guidelines set by the National Institutes of Health. ATA2 fusion peptide $(250 \mu \mathrm{g})$ emulsified in Freund's complete adjuvant was injected subcutaneously. An additional immunization was administered after 14 days using Freund's incomplete adjuvant. The animals were bled 2 weeks later, and the antibody titer specific for the original antigen was measured by ELISA. The antisera were then affinity-purified to the original antigen conjugated to nitrocellulose [20]. Specificity for native ATA2 protein was established by comparison of the affinity-purified antisera to preabsorbed antisera in Western blots of HPMV proteins.

Western blotting. The amount of ATA2 protein present in liver tissue and HPMVs was determined by Western blot [1]. Proteins, $100 \mu \mathrm{g}$, were separated through a $10 \%$ SDS-PAGE and blotted to nitrocellulose. After blocking with 3\% BSA in TBST for $2 \mathrm{~h}$, the blot was incubated with a 1:100 dilution of affinity-purified anti-ATA2 overnight at $4{ }^{\circ} \mathrm{C}$. Binding of antiATA2 was detected by incubation with secondary al- kaline-phosphatase conjugated anti-rabbit $\mathrm{IgG}$ followed by visualization with BCIP/NBT.

Northern blotting. Partial hepatectomies were performed on rats as described above, and total RNA was isolated from flash frozen liver harvested $0,3,6$, and 12 $\mathrm{h}$ following surgery using a modification of the acid phenol extraction method (Trizol, Gibco BRL, Grand Island, NY). Northern blotting was by standard methodology [1]. Denaturing formaldehyde gels were run using $15 \mu \mathrm{g}$ of RNA per lane followed by blotting to nitrocellulose membranes. High specific activity singlestranded riboprobe was generated using $\left[{ }^{32} \mathrm{P}\right] \mathrm{ATP}, \mathrm{T} 4$ RNA polymerase (Ambion, Austin, TX), and HindIIIdigested pCRII:ATA2(0-1) as a template. Labeled probe was separated from unincorporated $\left[{ }^{32} \mathrm{P}\right] \mathrm{ATP}$ by gel filtration. Hybridization was performed at $42{ }^{\circ} \mathrm{C}$ in $50 \%$ foramide, $5 \times \mathrm{SSC}, 0.1 \%$ SDS containing $10 \mu \mathrm{g} / \mathrm{ml}$ sheared herring testis DNA for 16-24 h. Blots were washed twice in $1 \times \mathrm{SSC}$ for $10 \mathrm{~min}$ at room temperature followed by 3 washes for $10 \mathrm{~min}$ at $42{ }^{\circ} \mathrm{C}$ in $0.1 \times \mathrm{SSC}$. Washing was completed with 3 high-stringency washes in $0.01 \% \mathrm{SSC}$ at $42{ }^{\circ} \mathrm{C}$ for $10 \mathrm{~min}$ each. Hybridized ATA2 probe was then visualized using a Molecular Dynamics SF phosphorimager.

Expression of System A activity from regenerating liver $m R N A$ in oocytes. Liver tissue samples were collected at 6 and $12 \mathrm{~h}$ following PH and frozen in liquid nitrogen. Control tissue was collected from resected liver at the time of surgery. mRNA was isolated from liver tissue using a direct mRNA isolation kit (Oligotex, QIAgen, Inc.). RNA quantity and quality were determined by ultraviolet spectroscopy and denaturing agarose electrophoresis, respectively, before injection of oocytes.

Frogs, Xenopus laevis, were kept in tanks of dechlorinated tap water on a 12 -h light/dark cycle at $19^{\circ} \mathrm{C}$ and fed a diet of dehydrated liver in Xenopus 1 chow three times per week. Frogs were anesthetized by immersion in cold $0.12 \% 3$-aminobenzoic acid ethyl ester for 20 min. Ovarian lobes were removed through a small incision in the frog's abdomen and placed in a modification of Barth's solution $(88 \mathrm{mM} \mathrm{NaCl}, 1 \mathrm{mM} \mathrm{KCl}, 2.4$ $\mathrm{mM} \mathrm{NaHCO}, 10 \mathrm{mM}$ Hepes, $0.82 \mathrm{mM} \mathrm{MgSO}_{4}, 0.33$

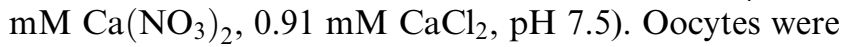
further treated as described below before injection of mRNA.

Before microinjection of mRNA into oocytes, the oocytes were incubated in a collagenase solution to remove the follicular cell layer using standard protocols. An aliquot of mRNA $(1 \mathrm{mg} / \mathrm{ml})$ was drawn into a glass micropipette $(10-20 \mu \mathrm{m}$ tip size) and $50 \mathrm{nl}$ injected into the animal/vegetal pole equator for cytoplasmic delivery. After injection, the oocytes were placed into incubation media $\left(96 \mathrm{mM} \mathrm{NaCl}, 2 \mathrm{mM} \mathrm{KCl}, 1.8 \mathrm{mM} \mathrm{CaCl}_{2}\right.$, $1 \mathrm{mM} \mathrm{MgCl} 2,5 \mathrm{mM}$ Hepes (pH 7.5), 10,000 U/L penicillin, $10 \mathrm{mg} / \mathrm{ml}$ streptomycin, $0.5 \mathrm{mM}$ theophylline, and $2 \mathrm{mM}$ pyruvate) and left at $1822{ }^{\circ} \mathrm{C}$ for 3 days to 
provide sufficient time for development of transporter activity from the injected mRNA. Incubation media were changed daily [17].

Oocyte amino acid transport assay. System A transport activity was determined as previously described $[27,40]$. Briefly, oocytes were incubated in a sodium-free modification of incubation media to partially deplete intracellular sodium pools. Some oocytes were placed into a sodium-containing buffer with $100 \mu \mathrm{M}\left[{ }^{14} \mathrm{C}\right] \mathrm{MeAIB}$, while other oocytes were placed into sodium-free buffer containing $100 \mu \mathrm{M}\left[{ }^{14} \mathrm{C}\right] \mathrm{MeAIB}$. The oocytes were exposed to the MeAIB for $60 \mathrm{~min}$ before rapid washing 3 times in ice-cold buffer lacking MeAIB. Oocytes were transferred to individual scintillation vials and solubilized in $1 \%$ SDS. Scintillation fluid was added, and the amount of MeAIB taken up by the oocytes quantified. Water-injected oocytes were included as controls.

Statistical analysis. All data are representative of at least 3 independent experiments. Multiple linear regression was used to analyze the kinetic data and $R^{2}$ values less than 0.90 were rejected. Kinetic data displaying a curvilinear Eadie-Hofstee plot were analyzed by computer modeling (SigmaPlot 4.01, SSPE, Inc., Chicago, IL). Curvilinear kinetic plots were mathematically modeled to fit only two independent MichaelisMenton components. Least-squares approximation of the equation of the hyperbola describing the putative two independent transport components was fitted to two theoretical linear components and tested for correlation. Correlation coefficients between the experimental data and the theoretical curves less than 0.95 were rejected.

\section{Results}

\section{Localization of the ATA2 gene product following partial hepatectomy}

Because the highly-regulated System A amino acid transport activity and ATA2 are synonymous [38], Western blotting of rat HPMV proteins retaining the severalfold induction in System A uptake activity observed following PH [12] was done to check for correlation between ATA2 protein levels and transporter activity. As seen in Fig. 1, affinity-purified anti-ATA2 specifically recognized a $42-$ to $43-\mathrm{kDa}$ protein in HPMVs that displayed increasing intensity in HPMVs at 6 and $12 \mathrm{~h}$ following PH. The appearance of increased ATA2 in HPMVs correlates well with the System A uptake activity measured in HPMVs following PH. We have previously shown that basal System A transport activity as assayed by $\mathrm{Na}^{+}$-dependent MeAIB uptake by HPMVs is barely discernable but rises approximately 3fold by $8 \mathrm{~h}$ after PH [12]. A surprising result was the high level of ATA2 protein in whole liver which did not increase following PH. The intensity of ATA2 content in HPMV identified by immunoblotting increased by $122 \pm 40 \%$ between 6 and $12 \mathrm{~h}(P<0.05)$. The content of ATA2 in immunoblots of total liver homogenate was not different over the time course of liver regeneration with the intensity $6 \mathrm{~h}$ equaling $88 \pm 15 \%$ of that at $12 \mathrm{~h}$ (no significant difference). This distribution of ATA2 protein suggests that a putative regulatory mechanism for ATA2-mediated transport activity is the recruitment of a large intracellular pool of ATA2 protein from an intracellular compartment to the plasma membrane.

\section{Steady-state mRNA level of ATA2}

Northern hybridization of an ATA2 probe to liver RNA resulted in the identification of homologous mRNAs of approximately $4.5 \mathrm{~kb}$ exactly as previously reported by Sugawara et al. [38]. As seen in Fig. 2, the ATA2 steady-state mRNA levels were remarkably similar at 3, 6, and $12 \mathrm{~h}$ following PH. We have previously shown that these mRNA levels are not markedly different from sham-operated animals [13]. The level of ATA2 mRNA may have been increased $3 \mathrm{~h}$ following PH by $26 \pm 8 \%$, but did not reach a level of statistical significance (percentage of sham control). At 6 and $12 \mathrm{~h}$, ATA2 mRNA following PH was not different from control levels $(21 \pm 14$ and $11 \pm 9 \%$, respectively).

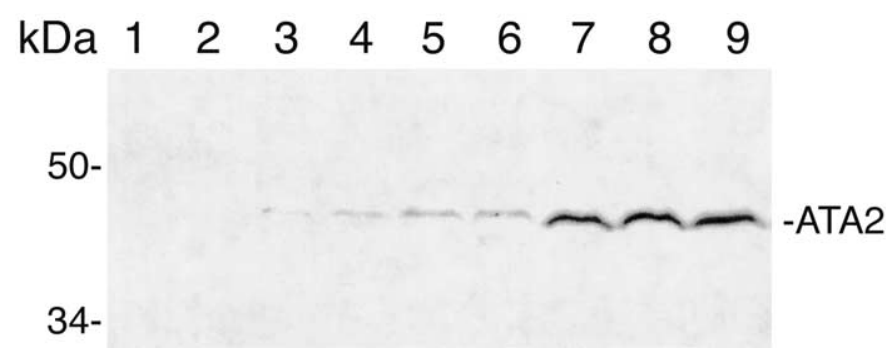

Fig. 1. The level of ATA2 gene product in hepatic plasma membrane vesicles and unfractioned liver protein. Shown is a representative immunoblot of three experiments. Total liver proteins (lanes 7-9) or proteins from isolated liver plasma membranes (lanes 1-6) were separated by SDS-PAGE, transferred to nitrocellulose, and probed with affinity-purified anti-ATA2 as described under Materials and methods. Protein samples were collected at 0 (lanes 1, 2, and 7), 6 (lanes 3, 4, and 8), or $12 \mathrm{~h}$ (lanes 5, 6, and 9) following PH. The ATA2 content as the average of densitometric analyses (percentage of time zero) is reported in the text. 


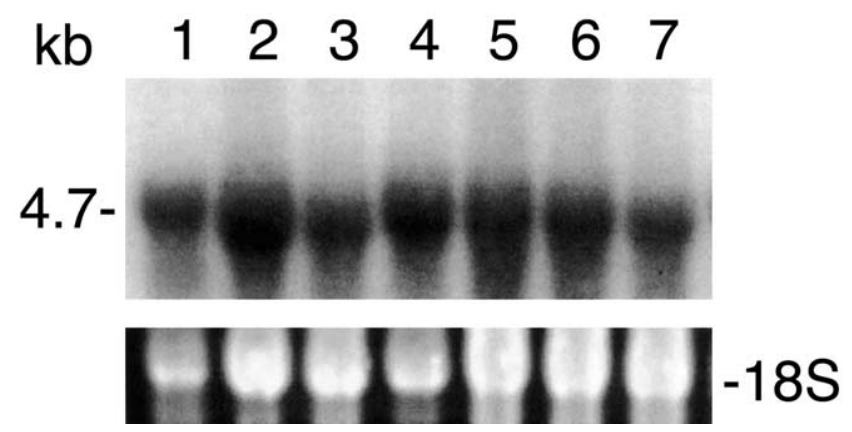

Fig. 2. Liver ATA2 mRNA steady-state levels following PH. RNA isolated from liver following PH 0 (lane 1), 3 (lanes 2 and 3), 6 (lanes 4 and 5), and $12 \mathrm{~h}$ (lanes 6 and 7) following surgery was subjected to Northern hybridization to a ${ }^{32} \mathrm{P}$-labeled ATA2 probe as described under Materials and methods. The percentage of sham-operated control is reported in the text.

Regardless of the potential slight increase in ATA2 mRNA at $3 \mathrm{~h}$, there is no change in the amount of total ATA2 gene product in liver at 6 and $12 \mathrm{~h}$. Our results show no significant change in ATA2 mRNA following $\mathrm{PH}$ and correlate well with the stable amount of ATA2 protein observed in whole liver tissue during a 12-h period of liver regeneration.

\section{Appearance of System A-activating mRNA following partial hepatectomy}

Previous phenomenological studies utilizing vesicles or cells have proposed that up-regulation of System Amediated transport activity is dependent on the de novo synthesis of mRNAs [19]. Because the steady-state level of ATA2 mRNA was unchanged following PH, our data did not correspond with these prior observations of others. To address this lack of correlation, we measured the System A activity expressed in oocytes from mRNA isolated from regenerating liver. Despite the marked increase in MeAIB uptake velocity in plasma membrane vesicles at $6 \mathrm{~h}$, there was no augmentation of basal System A transport activity in oocytes microinjected with mRNA isolated from regenerating liver at $6 \mathrm{~h}$ (Fig. 3) compared to presurgical values. However, increased System A activity was observed in oocytes injected with mRNA collected from regenerating liver $12 \mathrm{~h}$ after $\mathrm{PH}$, a finding inconsistent with the unchanged steady-state level of ATA2 mRNA found in regenerating liver (Fig. 2). These data indicate a fundamental difference between the ATA2 mRNA level measured in liver following PH and the appearance of System A-activating mRNAs isolated from regenerating liver at the corresponding time points.

\section{System A activity following partial hepatectomy}

Because of the discrepancy between the oocyte expression of System A activity and Northern analysis of

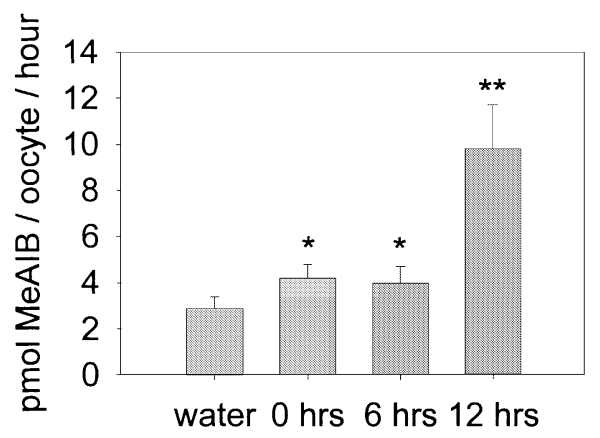

Fig. 3. Expression of regenerating rat liver mRNA in oocytes. RNA was isolated from regenerating liver 0,6 , or $12 \mathrm{~h}$ following $\mathrm{PH}$ and injected into oocytes to measure the appearance of System A-activating mRNAs as described under Materials and methods. Water-injected oocytes were included as controls. Data are the means \pm SD of 6 oocytes, injected in a paired manner, and are representative of 3 experiments.

ATA2 steady-state mRNA levels, the $\mathrm{Na}^{+}$-dependent uptake of MeAIB was examined by analysis of its kinetic properties in an attempt to resolve the conflicting find-

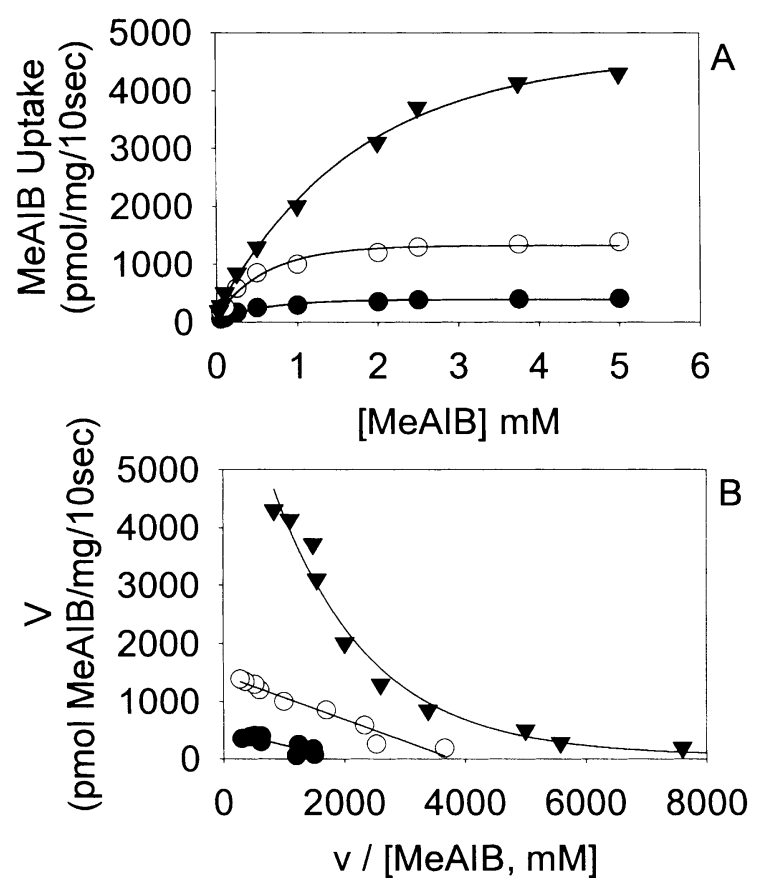

Fig. 4. Sodium-dependent uptake of MeAIB into hepatic plasma membrane vesicles. Vesicles were prepared from regenerating liver at 0 $(\bullet), 6(\bigcirc)$, and $12(\boldsymbol{\nabla}) \mathrm{h}$ following PH. Transport of 0.005 to $5 \mathrm{mM}$ MeAIB was determined as described under Materials and methods (A). Panel B summarizes the evaluation of Michaelis-Menton components to transport in hepatic plasma membrane vesicles. A single component to transport was identified at 0 and $6 \mathrm{~h}$ with a $K_{\mathrm{m}}$ of $0.24 \pm 0.06$ or $0.38 \pm 0.03 \mathrm{mM}$ and a $V_{\max }$ of $484 \pm 55$ or $1454 \pm 60$ $\mathrm{pmol} \mathrm{MeAIB} / \mathrm{mg}$ protein $/ 10 \mathrm{~s}$, respectively. Two components to transport were identified at $12 \mathrm{~h}$ with a $K_{\mathrm{m}}$ of $0.27 \pm 0.3$ or $5.62 \pm 0.42$ $\mathrm{mM}$ and a $V_{\max }$ of $1530 \pm 220$ or $6530 \pm 430 \mathrm{pmol} \mathrm{MeAIB} / \mathrm{mg}$ protein/ $10 \mathrm{~s}$ for the high- and low-affinity components, respectively. Data are representative of three vesicle preparations. 
ings. The kinetic data and their derivation are summarized in Eadie-Hofstee plots shown in Fig. 4. Reflecting the low System A activity in normal adult rat liver, HPMVs prepared from sham animals were found to contain a minimal level of System A transport activity. The basal System A transport determined from vesicles prepared from presurgery quiescent liver was characterized by a low level of activity with a calculated $V_{\max }$ of $484 \pm 55$ pmol MeAIB mg protein ${ }^{-1} 10 \mathrm{~s}^{-1}$ and $K_{\mathrm{m}}$ of $0.24 \pm 0.06 \mathrm{mM}$. Plasma membrane vesicles prepared $6 \mathrm{~h}$ following PH contained a markedly elevated System A activity. The kinetic analysis of System A amino acid transport at $6 \mathrm{~h}$ following $\mathrm{PH}$ revealed a $V_{\max }$ of $1454 \pm 60 \mathrm{pmol} \mathrm{MeAIB} \mathrm{mg} \mathrm{protein}^{-1} 10 \mathrm{~s}^{-1}$ with a $K_{\mathrm{m}}$ of $0.38 \pm 0.03 \mathrm{mM}$. Only one statistically significant component to transport at $6 \mathrm{~h}$ following $\mathrm{PH}$ was discernable by kinetic analysis of MeAIB uptake. The $K_{\mathrm{m}}$ of System A activity at 0 and $6 \mathrm{~h}$ following $\mathrm{PH}$ are consistent with values reported in the literature for ATA2 [33,38], indicating that the transport activity is mediated by the ATA2 gene product. A high $K_{\mathrm{m}}$ component to System A activity appeared at $12 \mathrm{~h}$ following $\mathrm{PH}$ with a $K_{\mathrm{m}}$ of $5.62 \pm 0.42 \mathrm{mM}$ and a $V_{\max }$ of $6530 \pm 430 \mathrm{pmol}$ MeAIB mg protein ${ }^{-1} 10 \mathrm{~s}^{-1}$. The $V_{\max }$ of the low $K_{\mathrm{m}}$ System A component at $12 \mathrm{~h}$ displayed an increase in $V_{\max }$ at $12 \mathrm{~h}$, relative to uptake at $6 \mathrm{~h}$, with almost no change in $K_{\mathrm{m}}$ Thus, the kinetic analysis of System A activity at $12 \mathrm{~h}$ indicates the appearance of a high $K_{\mathrm{m}}$ transport activity, and an additional increase in $V_{\max }$ for the low $K_{\mathrm{m}}$ uptake component. These data provide biochemical evidence for the stepwise appearance of two distinct System A transport activities following $\mathrm{PH}$ the low $K_{\mathrm{m}}$ component of which can be attributed to the ATA2 gene product while the high $K_{\mathrm{m}}$ component appears to result from either another gene product or, less likely, a modification of the ATA2 transporter.

\section{Inactivation of MeAIB transport by NEM}

Inherent differences in System A transport between normal liver and transformed hepatic cell lines have been previously suggested by differential responses to sulfhydryl-specific reagents [6,7]. NEM decreased System A-mediated transport in normal hepatocytes, but did not affect System A activity in hepatoma cells [6,7]. In the present study, the effect of chemical modification by NEM on each of the two components to System A activity after $\mathrm{PH}$ was tested for corroborative evidence for the presence of distinct System A transporters. We found that the System A transport component present in HPMV $6 \mathrm{~h}$ following PH was almost completely inactivated by NEM treatment, while the transport activity in HPMV at $12 \mathrm{~h}$ was resistant to NEM (Fig. 5). These findings agree with the kinetic and oocyte expression data indicating two distinct transport activities comprising System A in regenerating liver following $\mathrm{PH}$.

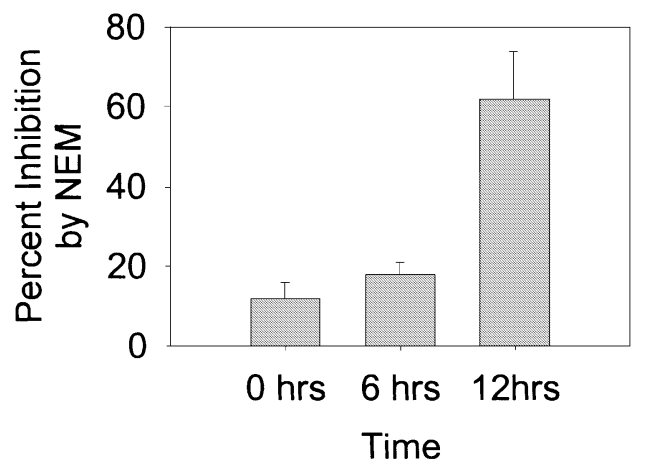

Fig. 5. Inhibition of transport by NEM. HPMVs were isolated from regenerating liver 0,6 , or $12 \mathrm{~h}$ following $\mathrm{PH}$ and the inhibition of 50 $\mu \mathrm{M}$ MeAIB uptake by $1 \mathrm{mM}$ NEM was determined as described under Materials and methods. Data are the means \pm SD of 3 determinations.

\section{Discussion}

The production of an anti-ATA 2 antibody provides a method for the direct examination of the amount of ATA2 gene product in subcellular fractions without the absolute requirement for the transport protein to be in a state suitable for the assaying of its activity. For example, the measurement of System A in Golgi [4] would not have been possible if the transporter was not active in vesicular preparation of subcellular fractions (a fortuitous situation), and the direct measurement of relative transporter protein level has not been previously possible, making characterization of the gene product impractical. Our findings indicate that the amount of ATA2 gene product in the hepatic plasma membrane increases while the total amount present remains constant. Since the amount of ATA2 protein in the cell, on a per milligram protein basis, is much higher than the amount of ATA2 appearing in the hepatic membrane following $\mathrm{PH}$, we hypothesize that the mechanism of upregulating ATA2-mediated amino acid transport is by a redistribution of ATA2 protein from an intracellular compartment to the plasma membrane. The lack of an increase in the steady-state level of ATA2 mRNA, taken in the context of no increase in the amount of ATA2 gene product in whole cell lysate following PH, supports the hypothesis that regulation occurs after the transcription and translation of the ATA2 gene.

Recently, others have reported a correlation between the steady-state ATA2 mRNA level and ATA2-mediated amino acid uptake [16], as well as a change in the subcellular location and amount of the ATA2 gene product [28], in an in vitro model of System A activity induction through the process of adaptive regulation. Adaptive regulation is the up-regulation of System A activity by cells incubated in media devoid of amino acids and the subsequent decay of transport upon the addition of a single System A amino acid substrate. While the study of adaptive regulation of ATA2 will no 
doubt reveal unique insight to the regulation of ATA2mediated transport, these observations are not likely to directly apply to the $\mathrm{PH}$ model because amino acids are readily available in vivo and the concentrations of System A substrate amino acids in peripheral blood actually increase following $\mathrm{PH}$ [14].

The hypothesis that System A activity can be increased in the absence of de novo mRNA and protein synthesis has been previously postulated [15,27]. Gazzola et al. [15] describe a starvation-enhanced increase in L-proline transport (attributed to System A) by fibroblasts in a cycloheximide-insensitive process. In addition, the division of System A activity into mRNA-dependent and mRNA-independent components has been described by Lin et al. [27]. In their investigations, insulin treatment of GF-14 lymphocytes resulted in increased System A uptake activity and increased expression of System A-like transport activity in oocytes injected with fractionated mRNA. These data suggest that System A activity is regulated by the transcription of System A-activating mRNAs, presumably those of the transporter itself. However, in the same study, insulin treatment of Ehrlich cells resulted in increased System A transport activity with no significant change in the expression of System A activity in oocytes. Together, these observations indicated the existence of at least two isoforms of System A amino acid transporter which differ substantially in kinetic properties and mechanism of regulation.

Our observations indicate that both isoforms of System A transport activities are increased in liver following $\mathrm{PH}$, and that the mRNA-independent activity appears in HPMV before any System A-activating mRNAs are detected in oocytes. Because the System A activity present in liver at $6 \mathrm{~h}$ following $\mathrm{PH}$ does not correlate with the appearance of System A-activating mRNAs expressed in oocytes, this activity resembles the activity described in Ehrlich cells, while the System A activity in liver at $12 \mathrm{~h}$ mirrors the appearance of System A-activating mRNAs expressed in oocytes, suggesting a System A activity consistent with that found in GF-14 lymphocytes. The differential sensitivity to NEM of System A activity found in HPMV following PH provides additional evidence for the presence of two distinct activities in liver.

Indeed the recent cloning of ATA3 cDNA [39], which codes for a System A-like transport activity, correlates well with these findings. ATA3 is expressed almost exclusively in liver and skeletal muscle $[21,39]$ bringing the number of known System A-like transporters expressed in liver to 2 (ATA2 and ATA3). In addition, the reported $K_{\mathrm{m}}$ of ATA3 for MeAIB is in the 4-6 mM range which is consistent with the high $K_{\mathrm{m}}$ component to transport reported in this study. Finally, the presence of cysteine residues in ATA3 at amino acid positions 18 and 26, not found in ATA2, potentially confers, the sensitivity of the high $K_{\mathrm{m}}$ component of transport to NEM. If ATA3 is indeed responsible for the high $K_{\mathrm{m}}$ component to transport, our findings indicate that its activity is regulated by the steady-state level of activating mRNAs. However, assignment of ATA3 as the high $K_{\mathrm{m}}$ transport activity up-regulated in liver following $\mathrm{PH}$ has yet to be directly demonstrated, and evaluation of ATA3 following PH was beyond the scope of this investigation. However, we are in the process of developing the antibodies and nucleic acid probes to critically evaluate ATA3 in this model.

The up-regulation of System A-mediated amino acid transport following PH $[12,26,29]$ is integral to optimal liver regeneration [14]; however, the role of increased amino acid uptake following $\mathrm{PH}$ and liver regeneration has remained elusive. The appearance of two System Alike transport activities early in the liver regeneration process may help explain the difficulty in identifying a specific role for increased amino acid uptake in this model of cell proliferation and growth. There is a distinct possibility that each System A component performs a different physiological function during regeneration and that the mechanisms of induction and mode of action for each differ significantly. The findings presented in this study indicate that ATA2 is regulated by the redistribution of the ATA2 gene product to the plasma membrane following $\mathrm{PH}$ and suggest that the high $K_{\mathrm{m}}$ component to System A transport is regulated at the level of mRNA. Since the rate constants for each System A component differ by approximately one order of magnitude, the differential appearance of each system would potentially impact the rate at which substrate amino acids are available for intracellular processes. The well-documented induction of System A amino acid transport following $\mathrm{PH}[12,26]$ and exposure to glucagon $[4,19]$ and during movement into the cell cycle $[3,9]$ are examples of up-regulated amino acid transport presumably providing increased nutrition for regeneration, substrate for gluconeogenesis, and macromolecule precursors for cell proliferation, respectively. The difference in transport rate, and the resulting cytoplasmic availability of substrate [37], could regulate some of the processes fueled by System A transport activity. However, characterization of these amino acid transport systems at the molecular level is in its infancy, and the future unraveling of the role that each System A component plays in liver regeneration will enhance the understanding of this unique phenomenon.

\section{References}

[1] F.M. Ausubel, R. Brent, R.E. Kingston, D.D. Moore, J.G. Seidman, J.A. Smith, K. Struhl, Current Protocols in Molecular Biology, Wiley, New York, 1987.

[2] O. Bussolati, J. Uggeri, S. Belletti, V. DallAsta, G.C. Gazzola, FASEB J. 10 (1996) 920-926. 
[3] O. Bussolati, J. Uggeri, B.M. Rotoli, R. Franchi-Gazzola, G.C. Gazzola, Biochim. Biophys. Acta 1151 (1993) 153-160.

[4] R. Cariappa, M.S. Kilberg, J. Biol. Chem. 265 (1990) 1470-1475.

[5] T. Chiba, K. Kawai, K. Ikenaka, H. Nakamura, M. Okamoto, N. Harada, H. Tanaka, T. Shirasaka, S. Fujii, Biochim. Biophys. Acta 755 (1983) 420-427.

[6] T.C. Chiles, M.S. Kilberg, J. Cell Physiol. 129 (1986) 321-328.

[7] T.C. Chiles, K.L. Dudeck-Collart, M.S. Kilberg, Am. J. Physiol. 255 (1988) C340-C345.

[8] H.N. Christensen, Physiol. Rev. 70 (1990) 43-77.

[9] V. Dall'Asta, O. Bussolati, G.G. Guidotti, G.C. Gazzola, J. Biol. Chem. 266 (1991) 1591-1596.

[10] A.M. Diehl, R.M. Rai, FASEB J. 10 (1996) 215-227.

[11] N. Fausto, P.R. Shank, Hepatology 3 (1983) 1016-1023.

[12] F. Fowler, R.K. Banks, M.E. Mailliard, Hepatology 16 (1992) $1187-1194$.

[13] T.L. Freeman, M.E. Mailliard, Biochem. Biophys. Res. Commun. 278 (2000) 729-732.

[14] T.L. Freeman, H.Q. Ngo, M.E. Mailliard, Hepatology 30 (1999) 437-444.

[15] G.C. Gazzola, V. Dall'Asta, R. Franchi-Gazzola, O. Bussolati, N. Longo, G.G. Guidotti, Biochem. Biophys. Res. Commun. 120 (1984) $172-178$.

[16] R.F. Gazzola, R. Sala, O. Bussolati, R. Visigalli, V. Dall'Asta, V. Ganapathy, G.C. Gazzola, FEBS Lett. 490 (2001) 11-14.

[17] G.W. Gould, in: Membrane Protein Expression Systems: A User's Guide, Portland Press, London, 1994, pp. 243-274.

[18] J.W. Grishman, Cancer Res. 22 (1962) 842-845.

[19] M.E. Handlogten, M.S. Kilberg, J. Biol. Chem. 259 (1984) 3519 3525.

[20] E. Harlow, D. Lane, in: Antibodies: A Laboratory Manual, Cold Spring Harbor Press, Cold Spring Harbor, NY, 1988, pp. 313315.

[21] T. Hatanaka, W. Huang, R. Ling, P.D. Prasad, M. Sugawara, F.H. Leibach, V. Ganapathy, Biochim. Biophys. Acta 1510 (2001) $10-17$.

[22] D. Haussinger, F. Lang, W. Gerok, Am. J. Physiol. 267 (1994) E343-E355.

[23] G.M. Higgins, R.M. Anderson, Arch. Pathol. 12 (1931) 186-189.
[24] M. Kallenbach, N.O. Roome, R. Schulte-Hermann, Cell Tissue Kinet. 16 (1983) 321-332.

[25] K.S. Koch, H.L. Leffert, Cell 18 (1979) 153-163.

[26] A. LeCam, M. Rey, J. Fehlmann, P. Kitabgi, P. Freychet, Am. J. Physiol. 236 (1979) E594-E602.

[27] G. Lin, J.I. McCormick, R.M. Johnstone, Arch. Biochem. Biophys. 312 (1994) 308-315.

[28] R. Ling, C.C. Bridges, M. Sugawara, T. Fujita, F.H. Leibach, P.D. Prasad, V. Ganapathy, Biochim. Biophys. Acta 1512 (2001) 15-21.

[29] J. Martinez-Mas, B. Ruiz-Montasell, A. Felipe, J. Casado, M. Pastor-Anglada, FEBS. Lett. 329 (1993) 189-193.

[30] J.D. McGivan, Biochem. Soc. Trans. 24 (1996) 837-873.

[31] J. McGowan, V. Atryzek, N. Fausto, Biochem. J. 180 (1979) 25 35.

[32] V. Prpic, K.C. Green, P.F. Blackmore, J.H. Exton, J. Biol. Chem. 259 (1984) 1382-1385.

[33] R.J. Reimer, F.A. Chaudhry, A.T. Gray, R.H. Edwards, Proc. Natl. Acad. Sci. USA 97 (2000) 7715-7720.

[34] M.H. Saier, G.A. Daniels, P. Boerner, J. Lin, J. Membr. Biol. 104 (1988) 1-20.

[35] G. Sander, A.B. Pardee, J. Cell Physiol. 80 (1972) 267-271.

[36] J. Short, R.F. Brown, A. Husakova, J.R. Gilbertson, R. Zemel, I. Lieberman, Biochem. Biophys. Res. Commun. 23 (1973) 430 437.

[37] H.J. Sips, A.K. Groen, J.M. Tager, FEBS Lett. 119 (1980) 271 274.

[38] M. Sugawara, T. Nakanishi, Y. Fei, W. Huang, M. Ganapathy, F. Leibach, V. Ganapathy, J. Biol. Chem. 275 (2000) 16473-16477.

[39] M. Sugawara, T. Nakanishi, Y.J. Fei, R.G. Martindale, M.E. Ganapathy, F.H. Leibach, V. Ganapathy, Biochim. Biophys. Acta 1509 (2000) 7-13.

[40] R.W. Tarnuzzer, M.J. Campa, N. Qian, E. Englesberg, M.S. Kilberg, J. Biol. Chem. 265 (1990) 13914-13917.

[41] R. Taub, FASEB J. 10 (1996) 413-427.

[42] V. Varoqui, H. Zhu, D. Yao, H. Ming, D. Erickson, J. Biol. Chem. 275 (2000) 4049-4054.

[43] D. Yao, B. Mackenzie, H. Ming, H. Varoqui, H. Zhu, A. Hediger, D. Erickson, J. Biol. Chem. 275 (2000) 22790-22797. 